\title{
Exotic Tabanidæ.
}

BY S. W. WILLISTON.

Pangonja venosa Wiedemann, Auss. Zw. Ins. i, 87.-Brazil.

Two male specimens from Rio de Janeiro. The wings are wholly dark brown.

Pangonia fulvithorax Wiedemann, Dipt. Exot. 152; Auss. Zw. Ins. i, 89. -Brazil.

Male. Ocelli present. Eyes hairy. Antennæ slender, the second to the seventh annuli of the third joint of nearly equal length, the eighth as long as the three preceding together, gently tapering; first two joints black, with black hair; the third reddish yellow. Face conical, dark brown, slightly dusted with sparse black hair. Palpi slender, nearly black. Proboscis nearly as long as the head and thorax together. Beard dark brown, yellowish on the orbits above. Mesonotum and scutellum dark cinnamon brown, thickly covered with light yellow hair, Pleuræ and pectus dark brown with brown hair. Abdomen broad and thickset, dark shining brown, broadly covered with recumbent golden hair on the sides posteriorly. Legs nearly black, with black hair. Wings dark brown; first posterior cell closed before the border of the wing. Length $19 \mathrm{~mm}$.

Two specimens, Rio de Janeiro, H. H. Smith.

Pangonia unicolor Macquart, Dipt. Exot, Suppl. 1, 55, pl. iii, f. 6.-Brazil.

Numerous specimens. The antennæ are slender, the third joint but little expanded at the base, the second to the seventh annuli of the third joint of nearly equal length, the eighth as long as the three preceding together. The face is conically produced. The second joint of the palpi is as long as the third joint of the antennæ, and is slenderly crescentic in shape. A rudiment of a vein is present on the anterior branch of the third vein, but the first posterior cell is open. The proboscis is long, and the labium is coiled up within the buccal cavity, admitting of great extension.

Pangonia pyrausta Osten Sacken. Biol. Centr. Amer. Dipt. i, 43.- Mexico.

A single female specimen from Mexico agrees in all respects with the description of this species, save in the absence of the mesonotal stripe and the white hair of the abdomen, and in the third joint of antennæ being ferrugirous. 
Pangonia diaphana Schiner, Reise der Novara, Dipt, i,43. Chile

Two specimens from Brazil, agreeing well with the description. The palpi are long and slender; the basal annulus of the third antennal joint is thickened, and the last is long and style-like.

Pangonia arcuata, n. sp.

Eyes bare. Ocelli present. Front narrow; dark ochraceous, with a slender dark line in the middle. First two joints of the antennæ yellow, the third yellowish red; third joint considerably dilated at the base, the eighth annulus long, style-like. Face mostly yellowish in ground-color, lightly dusted, receding in profile. Palpi yellow, the second joint much elongated, arcuate and porrect, extending as far forward as do the antennæ. Proboscis stout, scarcely as long as the thorax, black. Mesonotum yellow, but little shining, thinly yellowish and blackish pilose. Pleuræ densely white pollinose and with white pile. Abdomen moderately elongated, shining, thinly black pilose, except on the hind margins of the segments where it is white: first segment light translucent yellow; second segment yellow with the anterior margin in the middle more or less brownish; third segment dark brown with the hind margin yellow; remaining segments nearly black, with the hind margin narrowly pallid yellow. Legs yellow, the hind tibiæ and tarsi for the most part brown. Wings tinged with brownish, in front yellowish; anterior branch of the third vein with a long stump; first posterior cell closed. Length $14 \mathrm{~mm}$.

Two specimens, Chapada, Brazil, H. H. Smith.

Pangonia flipalpis, n. sp.

Eves bare. Ocelli present. Front narrow; yellow, with a slender, denuded streak. First two joints of the antennæ yellow, the third orange-red; basal segment broad, the annulate portion slender, the terminal annulus long, style-like, as long as the preceding four annuli together. Palpi yellow, the second joint long, slender and arcuate. Proboscis stout, a little longer than the vertical diameter of the head, black, the labella short. Face receding in profile, covered with yellowish dust. Beard scant, nearly white. Mesonotum deep brown or black beneath the yellowish dust, forming three broad, nearly confluent stripes and leaving the lateral margins yellow. Pleuræ brown and yellowish, with white pile. Scutellum nearly black, whitish dusted. Abdomen elongate; first segment light yellow, with a black spot beneath the scutellum; second segment light yellow, with a black spot in the middle in front; third segment black, with the hind part yellow, the immediate margin pallid yellow; the remaining segments black, with a palid yellow hind margin. Legs black. Wings tinged 
with brown, in front yellowish; anterior branch of third vein with a long stump; first posterior cell closed. Length I 7, i $8 \mathrm{~mm}$.

Two specimens, Rio Paraguay, December, H. H. Smith.

Pangonia bullata, n. sp.

Female. Eyes bare. No ocelli. Front very narrow, the eyes nearly contiguous. Head and thorax black throughout. Face receding in profile. Palpi stout. Third joint of antennæ opaque deep black, not slender. Proboscis short. Thorax shining, with black hair. Abdomen inflated, black, with three broad red stripes, the medium one beginning beneath the scutellum, the others on the lateral margins. Venter red on the sides. Legs black. Wings deep brown; anterior branch of the third vein with a stump of a vein; first posterior cell closed. Length $7 \mathrm{~mm}$.

One specimen, South Africa.

Pangonia margaritifera Wiedemann, Auss. Zw. Ins. i, 88, - "AustralAsia."

Tabanus guttatus Donovon, Gen. Illustr. Entom.; Wiedemann, op. cit.

A single specimen from Queensland, agreing closely with Wiedemann's description.

\section{Chrysops intrudens, n. sp.}

Female. Front opaque light yellow, the vertical callosity brown, the frontal callosity oval, and shining amber-yellow. Antennæ slender, as long as the mesonotum, yellow, the second joint partly and the third joint wholly brown. Face light shining reddish yellow, opaque yellow on the sides and above. Mesonotum deep brown, with four opaque yellow stripes, of which the inner pair are connected by a yellowish, somewhat variable dust in front, where the stripes themselves are narrow. Pleuræ nearly black, with opaque spots. Scutellum red, shining. Legs yellowish red, the front and hind tibiæ, the front tarsi and the distal joints of the posterior tarsi brown. Wings brown with the following hyaline spots: the distal portion of the first and second basal cells, the anal cell, a triangle on the hind border in the fifth posterior cell and another in the second posterior cell extending into the third; the anal angle is subhyaline. Abdomen: first segment wholly light yellow; second segment light yellow with two black triangles, their apex in front; third segment black or dark brown with a median yellow stripe; fifth and following segments black or brown with three narrow yellow stripes. Length $8 \mathrm{~mm}$.

Male. First antennal joint a little thickened. Mesonotum darker colored, the inner pair of stripes not connected by yellowish dust. Abdomen black, the first segment on the sides, the broad anterior angles of the second segments, a slender median stripe beginning on 
the second segment, and a slender lateral stripe distally, light yellow. Hyaline spots of the basal and posterior cells smaller.

Three females and one male, Chapada, Brazil.

Chrysops varians Wiedemann, Auss. Zw. Ins. i, 208.-Brazil.

Male. Face light gray, the callosities shining yellowish brown. Antennæ elongate, nearly as long as the mesonotum, the first joint incrassate; yellow, the third joint brown. Thorax black; mesonotum with two slender median stripes and a broader lateral margin, opaque gray. Abdomen black or deep brown; second segment with the anterior angles yellow and three gray spots on the hind margin; third and following segments with a gray hind margin. Legs dark brown, the metatarsi yellowish. Wings dark brown; a hyaline spot across the outer part of the basal cells, another in the anal cell, a triangle in the fifth posterior cell, and the whole apex of the wing, except a border along the costa to the extreme tip, hyaline; anal angle subhyaline.

Female. Front with a very broad callosity; face mostly shining. Mesonotum less darkly colored, the stripes broader, and the inner pair nearly connected in front by a bluish gray pruinosity. Abdomen brown; angles of the second segment more broadly yellow, and the median gray triangle behind much larger. All the basal cells of the wings hyaline (the veins at the ends clouded only); fifth posterior cell more largely hyaline. Length $8 \mathrm{~mm}$.

Three females and two males, Chapada, Brazil.

Pelecorhynchus ornatus Schiner, Reise der Novara, Dipt. 78.-Auckland.

One specimen, Queensland, agreeing well with the description.

Selasoma tibialis Fabricius, Syst. Antl. 102 (Tabanus); Wiedemann, Dipt. Exot. i, 89 (id.); Auss Zw. Ins. i. 165 (id.); Macquart, Dipt. Exot. i, 2.South America (Wied.), Brazil (Macq.).

A number of specimens from Chapada, Brazil. I quite agree with Schiner that the differences between this genus and Hadrus Perty are trivial.

Hadrus lepidotus, Wieủemann, Auss. Zw. Ins. i, 193 (Tabanus); Perty, Delectus, etc. 183, pl. xxxvi, f. 9; Macquart, Dipt. Exot. i, l, 154, pl, xviii, f. 3 (Lepiselaga); Schiner, Reise der Novara, Dipt. 96. - South America, West Indies, Mexico.

Several specimens from Brazil.

Hadrus parvus, n. sp.

Female. Face, cheeks, and the callosity upon which the antennæ are situated deep black, shining. Front considerably broader below, where the width is equal to the length; for the most part shining black (there is some grayish dust below the vertical callosity and on 
the lateral margins). Antennæ ferriginous, the third joint black at the extremity. Palpi dark pitchy black. Thorax shining black, the mesonotum more brown and but little shining, and clothed with yellowish irridescent tomentum. Wings brown and hyaline; the brown extends as far as the tip of the first longitudinal vein, does not quite reach the hind border, and has an angular sinus extending to the fifth vein at the middle of the discal cell; a hyaline spot extends across the fourth vein a little in front of the discal cell. Legs deep brown; the four hind tarsi light yellow, the front metatarsi yellow or yellowish; all the tibiæ dialated. Length $5,6, \mathrm{~mm}$.

Two specimens, Rio Paraguay, H. H. Smith. This species is at once distinguishable from $S$. lepidotus by the smaller size and wider front. From S. (Hamatopota) crassipes Wied. it will be distinguished by the single hyaline spot of the wings and the yellow tarsi.

Diachlorus curvipes Wiedemann, Auss. Zw. Ins. i, 176 (Tabanus); Macquart Hist. Nat. Dipt. i, 208 (Diabasis). - South America.

Female. Front a little broader below, light opaque yellow, the prominent vertical tubercle clothed with short black hair, the black or deep brown, shining callosity broader than long. Antennæ red, the third joint blackish distally; second joint not more than onethird the length of the first, the third wholly without tooth. Face broadly swollen in the middle, shining yellowish brown, the orbits and the cheeks opaque yellow. Mesonotum on the sides and in front, and narrowly behind, as also a slender median stripe, covered with golden yellow pile; elsewhere the mesonotum is shining black. Scutellum covered with the same yellow pile. Pleuræ for the most part black, lightly pruinose; in front and below the wings yellow. Abdomen shining reddish or brownish yellow, with a slender median stripe of golden yellow pile. All the femora reddish or brownish yellow: the dilated front tibiæ and the front tarsi dark brown; hind tibiæ for the most part brown; middle tibiæ and their tarsi, except the terminal joints, light yellow. Wings yellowish hyaline, brownish in front, the apex brown. Length 9, ro $\mathrm{mm}$.

This description does not fully agree with the original, nevertheless there can be little doubt of the identity. Four specimens, Rio Paraguay, Dec., H. H. Smith.

\section{Dichelacera (Diachlorus?) scutellata, n. sp.}

Female. Front not more than twice as long as its greatest breadth, opaque light gray, with a large triangular callosity whose sides are convex, and which extends to the ocelli. Antennæyellow, the annulate portion of the third joint black and hairy; first joint four or five times the length of the short, globose second joint, the third joint longer than the first two together; third joint with a minute tooth 
above, the annulate portion as long as the basal portion. Face shining yellowish. Palpi brownish yellowish, large, Tabanus-like. Mesonotum polished brown, with two narrow whitish stripes in front; on the posterior part with bright yellow pile (it is possible that the yellow pile may be more extensive in perfectly fresh specimens). Abdomen brown with a median light yellow stripe. Legs brown, the hind tibiæ blackish. Wings hyaline with the anterior border to the apex, a moderately broad band beginning beyond the end of the first vein and extending into the fifth posterior cell, a cloud on the outer part of the third vein and on the posterior basal transverse vein, dark brown; anal angle subhyaline. Length 9, ro mm.

Four specimens, Chapada, Brazil. I cannot find any description which will apply to this species, nor am I confident where it should belong. It has the elongate form and the elongate first antennal joint of Dichelacera, but lacks the prominent process of the third antennal joint. The front tibiæ are slender, wherein it differs from the species of Diachlorus known to me.

\section{Stibasoma theotænia.}

? Tabanus theotcenia Wiedemann, Auss, Zw. Ins. i, 136; Schiner Reise der Novara, Dipt. 98 (Stibasoma).-Montevideo.

Male. Facets of eyes much enlarged on the upper part, small below; eyes bare. No ocelli. Process of third joint much enlarged and reaching as far forward as the non-annulate portion; style short. Face black, lightly dusted. Palpi black, with black pile. Thorax deep black, with black hair; mesonotum lightly whitish dusted above. Abdomen deep shining black throughout, and with black hair only. Legs deep black; front tibiæ dilated; hind tibiæ black-ciliate without and within. Wings deep brown, the apex cinereous hyaline. Length I $6 \mathrm{~mm}$.

One specimen, Chapada, Brazil. If this is the male of the true $S$. theotcenia, it differs very much in the color of the abdomen, which is given by Schiner as light yellow on the basal segments. As no male has been described in this genus, it is not at all impossible that such sexual differences may exist. That it is neither $S$. fulvohirtum or $S$. tristis is evident from the black wings, and, if the species is not $S$. theotenia it must be new, the female unknown.

\section{Tabanus.}

There are in my collection numerous species of Tabanus from South America, only a part of which I have been unable to identify so far. Notwithstanding this, it is probable that not a few of them have been described, and nothing will be gained by giving names to them now. 
Tabanus festivus, Wiedemann, Auss. Zw. Ins. i, 135.-Brazil.

One specimen, Chapada. The densely ciliate hind tibiæ, black in front and white behind, renders this handsome species easily recognizable.

Tabanus T-nigrum Fabricius, Syst. Antl., 101; Wiedemann, Auss. Zw. Ins. 1, 160.- South America.

Two females from Rio de Janeiro, November. The third joint of the antennæ, with its basal process, is very slender. The palpi also are unusually slender. The front tibiæ are brownish at the tip only, and all the tarsi have the three or four distal joints brown.

Tabanus leucaspis Wiedemann, Auss, Zw. Ins. i, 170.-Brazil.

Three specimens, Chapada. The basal process of the third antennal joint is a mere tubercle. The palpi brownish, the front tibiæ light yellow on the proximal third, the middle and hind pairs on the proximal half or two-thirds. Eyes bare, ocelli minute. The opaque white scutellum is a conspicuous characteristic of the species.

Tabanus unicolor Wiedemann, Auss. Zw. Ins. i, 141.-Brazil.

Two specimens, Uarcarizal, Febr. The third joint of the anten$\mathrm{n} æ$ is brown, with a moderately elongate basal process. The front is rather broad, wholly without denuded spots and without ocelli. Eyes bare.

Tabanus importunus Wiedemann, Auss. Zw. Ins. i, 127-Brazil.

Three specimens, Rio Paraguay, below Cuncepcion. The specimens agree with the description, except that the legs are more yellowish, with the tarsi brown or black. The third joint of the antennæ is in some specimens mostly black; its annulate portion is slender, the process above acute, but not produced.

Tabanus modestus Wiedemann, Auss. Zw. Ins i, 146.-Brazil.

The third joint of the antennæ in some specimens is wholly reddish yellow; in others with the short annulate portion blackish; its basal process is sub-angulate, not produced. The eyes in the female are wholly bare; thickly and distinctly pubescent in the male. There are no ocelli. In the male, the legs and antennæ are somewhat darker, but there is scarcely any other difference. Eight specimens, Chapada and Rio de Janeiro.

Tabanus quadripunctatus Fabricus, Entom. Syst. 99; Wiedeman, Auss. Zw. Ins. i, 150; Schiner, Reise der Novara, Dipt. 86.--Brazil.

A single specimen from Rio de Janeiro seems to be of this species. From Wiedemann's description it differs in not having a very strong tooth to the third joint, and in lacking the "Dornchen" on each side of the vertex. Schiner's description of the abdomen, but not of the legs, agrees better. All the tibiæ are blackish distally. The first posterior cell is narrowly open. 


\section{$2 \mathrm{BHL}$ Biodiversity Heritage Library}

Williston, Samuel W. 1895. "Exotic Tabanidae." The Kansas University quarterly 3, 189-195. https://doi.org/10.5962/bhl.part.15959.

View This Item Online: $\underline{\text { https://www.biodiversitylibrary.org/item/35118 }}$

DOI: https://doi.org/10.5962/bhl.part.15959

Permalink: https://www.biodiversitylibrary.org/partpdf/15959

\section{Holding Institution}

Harvard University, Museum of Comparative Zoology, Ernst Mayr Library

\section{Sponsored by}

Harvard University, Museum of Comparative Zoology, Ernst Mayr Library

\section{Copyright \& Reuse}

Copyright Status: NOT_IN_COPYRIGHT

This document was created from content at the Biodiversity Heritage Library, the world's largest open access digital library for biodiversity literature and archives. Visit BHL at https://www.biodiversitylibrary.org. 